\title{
Pengembangan Video Knowledge Capture Mata Kuliah Difusi Inovasi Pendidikan di Prodi Teknologi Pendidikan Universitas Negeri Jakarta
}

\author{
Ardiansyah , ${ }^{\square}$ Cecep Kustandi $^{2}$, Kunto Imbar Nursetyo ${ }^{3}$ \\ ${ }^{1}$ Universitas Negeri Jakarta, Jakarta, Indonesia. \\ ${ }^{2}$ Universitas Negeri Jakarta, Jakarta, Indonesia. \\ 3 Universitas Negeri Jakarta, Jakarta, Indonesia. \\ DOI: https://doi.org/10.21009/JPI.031.02
}

\begin{abstract}
Article History Abstrak
Received : 2020

Accepted : 2020

Published : 2020

\section{Keywords}

Keywords 1;

Pengembangan 2;

Video 3; Knowledge

Capture 4; Model

Video Nonlinear

Pustekkom.

Penelitian ini bertujuan untuk menghasilkan sebuah produk pengembangan berupa Video Knowledge Capture pada Mata kuliah Difusi Inovasi Pendidikan di Prodi Teknologi Pendidikan Universitas Negeri Jakarta. Diharapkan video yang dikembangkan dapat menjadi sumber belajar mahasiswa Teknologi Pendidikan. Pengembangan video knowledge capture ini menggunakan model pengembangan Video Nonlinear oleh Pustekkom, Model ini memiliki 3 tahapan besar dan sub tahapan disetiap tahapan. Penelitian ini melibatkan tiga tahap uji coba pramaster yaitu Expert review (Ahli Media dan Ahli Materi), One to One, dan Small Group. Evaluasi formatif yang dilakukan oleh peneliti mengacu pada Survey Web Bali Universitas Negeri Jakarta dan menggunakan skala likert yaitu 1-4. Hasil uji coba expert review 3,85 (Sangat Baik), Hasil uji coba one to one adalah 3,28 (Sangat Baik) dan Hasil uji coba Small Group adalah 3,42 (Sangat Baik). Secara keseluruhan dapat dikatakan media video knowledge capture yang dikembangkan layak untuk dijadikan bahan belajar.
\end{abstract}

\begin{abstract}
This research aims to produce video of knowledge capture for Educational Innovation Diffusion courses in Educational Technology, Universitas Negeri Jakarta. The development of this video is expected can be learning resources for student of Educational Technology. Development of Knowledge Capture Video uses the Model Video Nonlinear by Pustekkom, this model has 3 major stages and sub stages at each stages. This research involves three trials protester, consist of expert review, one to one, and small group. The development of knowledge capture video involves two expert review (review expert matter and media expert). Formative evaluation conducted by researchers refer to a survey web bali state university of Jakarta and uses a likert scale (1-4). Average result from expert review 3,85, One on one 3,28, and small group 3,42. Based on the result of these data, reseacrcher conclude that video knowledge capture worth to use as a source of learning.
\end{abstract}

\footnotetext{
${ }^{\otimes}$ Corresponding author : Ardiansyah

Adress: Universitas Negeri Jakarta

Jakata,50229

E-mail: Ardiansyahh@outlook.com
}

(C) 2020 Universitas Negeri Jakarta 


\section{Ardiansyah | JPI/Vol.o3/No.01/2020| H. 09 - 16}

\section{PENDAHULUAN}

Era Globalisasi sangat mempengaruhi perkembangan teknologi informasi dan komunikasi, salah satunya yaitu cara hidup masyarakat dalam melakukan kegiatan seharihari. Tidak hanya digunakan untuk berkomunikasi dan mendapatkan informasi, bahkan saat ini dalam bidang pendidikanpun teknologi informasi dan komunikasi dimanfaatkan sebagai sebuah media pembelajaran.

Hal tersebut tidak terlepas dari media pembelajar itu sendiri, yaitu sebagai perantara antara pengirim pesan (Guru) dan penerima pesan (Siswa). Menurut Yusufhadi Miarso (2009) berpendapat bahwa media pembelajaran adalah segala sesuatu yang digunakan untuk menyalurkan pesan serta merangsang pikiran, perasaan, perhatian, dan kemauan si belajar sehingga dapat mendorong terjadinya proses belajar yang disengaja, bertujuan, dan terkendali. Ditambahkan pendapat menurut Edgar Dale (Dalam Arsyad 2010) Penjelasan dalam kerucut pengalaman atau Cone of Experience bahwa pengunaan media pembelajaran dapat mempermudah peserta didik memahami yang abstrak menjadi konkrit.

Universitas Negeri Jakarta memiliki 8 Fakultas dan 1 Program sarjana, pada saat ini penulis akan berfokus pada Fakultasi Ilmu Pendidikan (FIP) khususnya prodi Teknologi Pendidikan. Pada saat ini prodi Teknologi pendidikan sedang mengembangkan pembelajaran Hybrid learning. Pembelajaran hybrid merupakan model pembelajaran yang mengkombinasikan pembelajaran tatap muka dengan pembelajaran online menurut Chen (2012). Dalam pembelajaran hybrid khususnya pada bagian online learning tentunya diperlukan konten-konten pendukung materi pembelajaran. Konten tersebut dapat berupa media visual, media audio ataupun media visual audio.

\section{Hybid Learning Fakultas Ilmu}

Pendidikan terdapat beberapa mata kuliah prodi Teknologi Pendidikan, satu diantaranya yaitu mata kuliah difusi inovasi pendidikan. Mata kuliah ini secara garis besar menjelaskan bagaimana aspek komunikasi mampu menyebarluaskan inovasi yang ada kepada para adopter. Jadi, dapat dikatakan bahwa mata kuliah ini memberikan pengetahuan mulai dari proses mengetahui arti inovasi tersebut hingga cara mendifusikan inovasi. Selain itu, Tujuan proses difusi adalah diadopsinya suatu inovasi oleh anggota system social tertentu. Anggota system social tersebut yaitu individu, kelompok informal, organisasi, dan subsistem (Rogers, 1995).

Berdasarkan hasil diskusi pengembang dengan salah satu dosen pengampu mata kuliah DIP yaitu Ibu Retno Widyaningrum, bahwa mahasiswa sering mengalami kesulitan dalam memahami materi yang bersifat konseptual dan prosedural. Walaupun, beliau sudah memberikan contoh terkadang masih banyak mahasiswa yang belum memahami. Pengembang juga melakukan diskusi bersama beberapa mahasiswa yang mengambil mata kuliah difusi inovasi pendidikan, mereka berpendapat bahwa materi yang diberikan 


\section{Ardiansyah | JPI/Vol.o3/No.01/2020| H. 09 - 16}

hanya sebatas lisan dan tanpa didukung oleh media visual. Materi yang sampaikan secara lisan tersebut, terkadang lupa untuk ditulis oleh mereka, sehingga materi dan contoh yang diberikan mereka tidak ingat.

Media Video dipilih bukan tanpa alasan, tetapi berdasarkan wawancara sebelumnya menurut Ibu Retno Widyaningrum materi yang bersifat konseptual dan procedural itu akan lebih mudah apabila disajikan dalam bentuk video. Diperkuat oleh Situmorang (2006) Materi yang dapat dipertimbangkan untuk suatu media video adalah materi yang berhubungan dengan proses, prosedural, sikap, faktual, materi yang sifatnya langka, materi yang memiliki resiko tinggi bila peserta didik berhadapan langsung dan materi yang membutuhkan aspek visual dalam pencapaian kompetensi.

Media video memiliki beberapa unsur media diantaranya visual, audio, serta text. Sehingga, media video merupakan salah satu media yang baik untuk pembelajaran. Menurut Levied \& Lentz (1982) dalam Cecep Kustandi (2011), terdapat empat fungsi media pembelajaran khususnya media visual, yaitu fungsi atensi, fungsi kognitif, dan fungsi kompensatoris. Media berbasis visual memegang peran yang sangat penting dalam proses belajar. Media visual dapat memperlancar pemahaman dan memperkuat ingatan.

Penggunaan video dalam pembelajaran akan lebih efektif dalam merangsang peserta didik dalam meningkatkan keinginan untuk tahu lebih dalam dan untuk mencari hal baru yang berkaitan dengan materi pembelajaran, sehingga tujuan pembelajaran akan lebih mudah untuk tercapai. Menurut Zhang D et al. "Bahkan dari perspektif siswa, video dapat menjadi media yang lebih efektif daripada teks karena meningkatkan kepuasan dan motivasi mereka selama proses pembelajaran."

$$
\text { Berdasarkan masalah diatas, }
$$

pengembang tertarik untuk mengembangkan sebuat media visual berupa video pembelajaran berupa Knowledge Capture yang materi tersebut mencakup pengetahuan konseptual dan prosedural. Salah satu materi yang mengandung pengetahuan konseptual dan prosedural yaitu pada materi pembelajaran yang membahas mengenai tahapan proses keputusan inovasi yang terdiri dari Pengetahuan - Persuasi - Keputusan - Implementasi - Konfirmasi.

Sharon E. Smaldino (2011) terdapat enam kategori dasar media adalah Teks, Audio, Visual, Video, Perekayasa, dan Orang. Tujuan dari penggunaan media adalah mempermudah komunikasi dalam belajar. Smaldino dalam bukunya juga menjabarkan media video berdasarkan Teknik mengambilan gambar diantaranya yaitu : Kunjungan Lapangan Virtual, Dokumenter, Dramatisasi, Penceritaan Kisah Lewat Video, Rekayasa Waktu, Rekayasa Tempat, dan Animasi.

Berdasarkan ketujuh Teknik yang dipaparkan Smaldino dalam bukunya, Media Video Knowledge Capture yang di kembangkan menerapkan Teknik Dramatisasi dan animasi dalam menyajikan materi, mata kuliah yang dikembangkan. Teknik Dramatisasi karena ditampilkan seolah-olah sedang berada didalam 
kelas dan dilengkapi dengan Motiongraphic yang untuk para mahasiswa tanpa terikat dengan termasuk ke dalam Teknik animasi.

Knowledge Capture merupakan salah satu komponen yang terdapat dalam Knowledge Management, Knowledge Capture merupakan bagian dari proses perubahan pengetahuan tacit knowledge menjadi explicit knowledge. Macammacam cara yang dapat kita lakukan dalam knowledge capture adalah Interview, OnSite Observation, Brainstorming, Concensus Decision Making, Nominal Group Technique, Delphi Method, Repertory Grid, Concept Mapping, dan Blackboarding. (Yolandha marsha, 200o). Pengembangan video akan menggunakan bentuk interview. Pertanyaan di berikan kepada Narasumber dalam bentuk motiongraphic. Interview dipilih karena prosesnya sederhana dan mudah dilakukan.

Berdasarkan masalah yang sudah dipaparkan bahwa, dalam penembangan media video ini ditujukan untuk mahasiswa semester 3 yang mengambil mata kuliah Difusi Inovasi Pendidikan. Hurlock dalam bukunya, dapat disimpulkan bahwa mahasiswa TP 2017 yang sedang ada di semester 3 termasuk kedalam golongan Dewasa Dini. Manusia yang ada pada tahap Dewasa Dini yaitu peralihan dari masa remaja ke dewasa, jadi mereka akan lebih nyaman dalam belajar apabila dapat mengaksesnya sendiri. Mereka cenderung, untuk mengerjakan segala sesuatu secara mandiri, tidak terkecuali dalam belajar mereka. Mereka akan menyenangi belajar secara sendiri, salah satunya yaitu menggunakan media video. Media Video dapat dijadikan bahan belajar waktu, mereka dapat mengakses video tersebut kapan saja dan dimana saja. Oleh karena itu, Pengembang memilih media video untuk di kembangkan.

Pengembangan media video ini, sebelumnya dilatar belakangi karena belum adanya media pembelajaran berupa video yang dimanfaatkan dalam pembelajaran. Banyak sekali mahasiswa kurang paham apabila materi disampaikan dengan cara ceramah, sehingga mereka membutuhkan media lain yang dapat membantu mereka untuk belajar, Pengembangan media video akan menggunakan model pengembangan video nonlinear oleh Pustekkom. Model ini terdiri dari 3 tahapan utama dan 3 subtahapan disetiap tahapannya. 3 Tahapan tersebut yaitu : 1). Tahapan Perencanaan (Analisis Kebutuhan, Penyusunan GBIM \& JM, Penulisan Naskah), 2). Tahapan Produksi (Persiapan, Pelaksanaan, dan Penyelesaian), dan 3) Tahapa Evaluasi (Pramaster, Revisi, Uji Lapangan).

\section{METODE}

Metode pengembangan menggunakan Research and Development (R\&D) dengan model pengembangan video nonlinear oleh Pustekkom. Model ini terdiri dari 3 tahapan utama dan 3 subtahapan disetiap tahapannya. 3 Tahapan tersebut yaitu : 1). Tahapan Perencanaan (Analisis Kebutuhan, Penyusunan GBIM \& JM, Penulisan Naskah), 2). Tahapan Produksi (Persiapan, Pelaksanaan, dan Penyelesaian), dan 3) Tahapa Evaluasi 
(Pramaster, Revisi, Uji Lapangan). Penelitian dilakukan di Prodi Teknologi Pendidikan Universitas Negeri Jakarta dan waktu penelitian dilakukan pada bulan April-Agustus 2019. Diawali dengan melakukan analisis kebutuhan dengan cara berdiskusi dengan dosen pengampu mata kuliah. Barusalah penyusunan GBIM dan JM, setelah dilakukan tahap selanjutnya membuat naskah dan masuk ketahap produksi hingga penyelesaian. Dalam Penelitian ini uji coba produk dilakukan dengan melibatkan beberapa responden. Responden yang terlibat diantaranya ahli Materi, ahli Media, dan Peserta Didik. Hal ini dilakukan untuk menilai kelayakan produk yang dikembangkan, Teknik pengambilan data yang digunakan yaitu menggunakan Intrument Kuesioner yang telah dikembangkan oleh dosen Teknologi Pendidikan Universitas Negeri Jakarta pada situs web-bali, khususnya Kuesioner produk pengembangan Video. Uji coba yang dilakukan tidak sesuai dengan model karena adanya keterbatasan waktu. Uji coba hanya dilakukan dengan cara expert review, one to one, dan small group. Untuk uji lapangan hanya dibuatkan kisikisi serta instrument guna menilai hasil belajar setelah menggunakan media.

\section{HASIL DAN PEMBAHASAN}

Penelitian pengembangan dilaksanakan pada prodi Teknologi Pendidikan, Universitas Negeri Jakarta. Penelitian ini akan dilaksanakan mulai dari bulan April - Agustus 2019. Pengembangan video Knowledge Capture ini melibatkan pengkaji dan responden yang akan mengkaji dan menilai dalam uji coba produk yang dikembangkan. Pengkaji dan responden yang akan terlibat dalam penelitian pengembangan video Knowledge Capture ini, adalah : Expert review adalah mereka para ahli yang akan terlibat dalam mengevaluasi proses pengembangan produk video Knowledge Capture yang akan dikembangkan. Expert review dalam penelitian pengembangan ini, Ahli Media dan Ahli Materi. Responden dalam penelitian ini yaitu, para Mahasiswa/I Teknologi Pendidikan, Universitas Negeri Jakarta yang sedang atau sudah mengambil mata kuliah Difusi Inovasi Pendidikan.

Instrumen yang akan digunakan pada pengembangan media video Knowledge Capture ini yaitu kuesioner. Kuesioner akan diberikan kepada ahli media, ahli materi, dan para mahasiswa, untuk menilai kualitas produk yang dikembangkan. Kuesioner yang digunakan kepada para ahli dan pengguna yaitu kuesioner yang dikembangkan oleh Prodi Teknologi Pendidikan Universitas Negeri Jakarta yang terdapat dalam website http://survey.webbali.net/ Khususnya untuk Media Video pada kuesioner yang terdapat pada website tersebut. Pada kuesioner memiliki kolom masukan untuk memberikan kritik, masukan, dan saran yang berguna untuk evaluasi akhir mengenai produk yang dikembangkan.

Tahapan pertama yaitu perencanaan Pada tahap ini terdiri dari 3 subtahapan diantaranya yaitu Analisis kebutuhan, menyusun GBIM \& jabawan materi, dan Penulisan Naskah. Setiap subtahapan yang ada dilakukan secara sistematis. 
Tahapan Kedua yaitu produksi, pada tahap ini terdiri 3 subtahapan yaitu persiapan, pelaksanaan dan penyelesaian. Pada tahap ini dihasilkan output berupa storyboard dan video knowledge capture. Pada tahap ini digambarkan mulai dari proses shooting hingga editing.

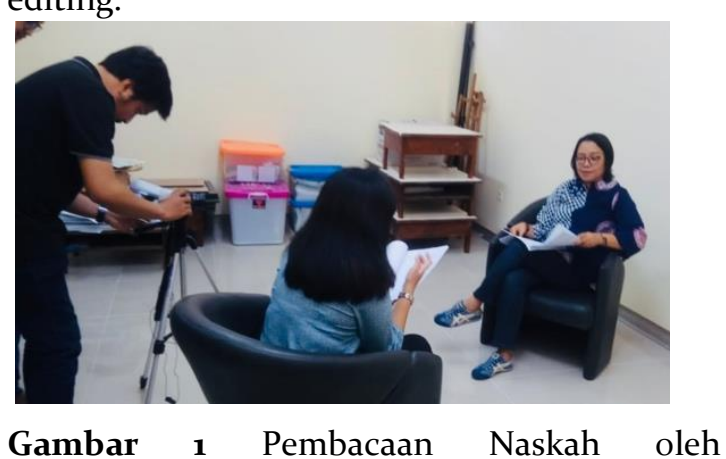

Naraasumber

Gambar diatas merupakan termasuk kedalam tahapan pelaksanaan, dimana sebelum dilakukan proses shooting. Pemeran yaitu Narasumber mempelajari naskah yang sudah dibuat sebelumnya.

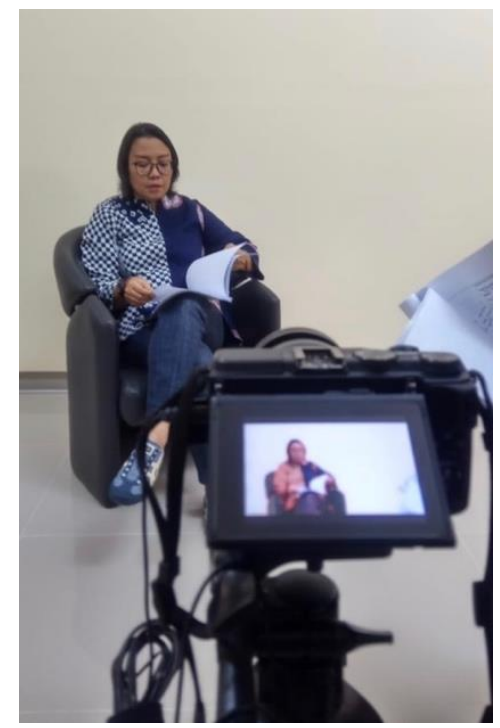

Gambar 2 Proses Perekaman Video

Setelah dilakukan pembacaan naskah, selanjutnya yaitu proses shootng. Mengikuti arahan sutradara dan juga naskah serta storyboard yang sudah dibuat sebelumnya.

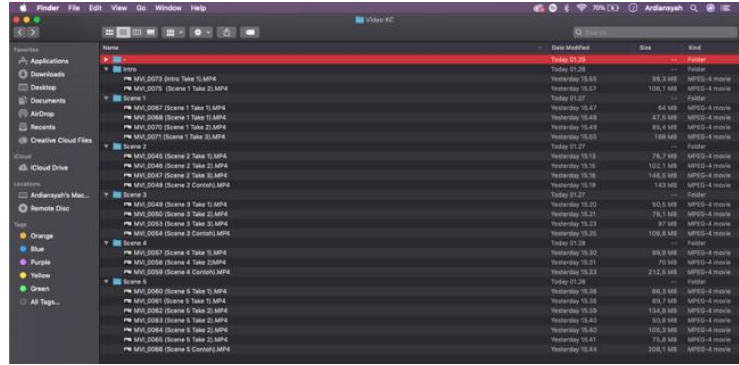

Gambar 3 Pemilihan Video

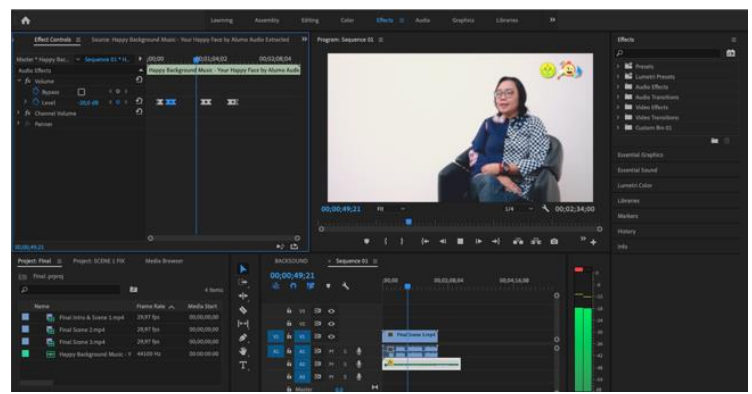

Gambar 4 Memotong dan Menambahkan Suara

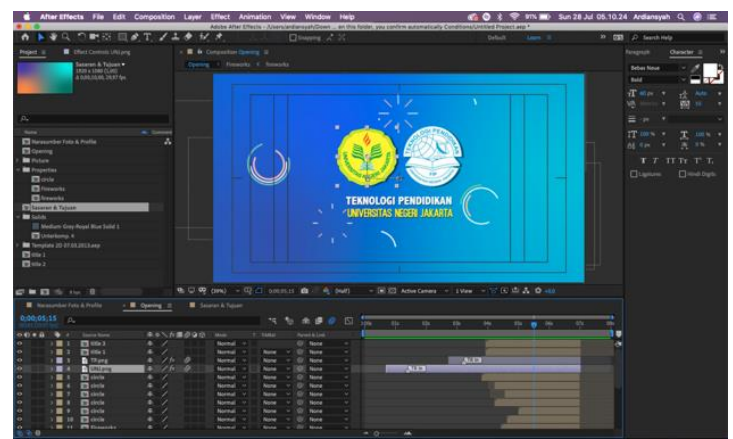

Gambar 5 Motion Graphic di Adobe After Effect

Pemilihan Video dilakukan sebagai rangkaian dalam subtahapan penyelesaian (Pasca produksi). Pada tahap ini dilakukannya proses pemilihan video dan editing. Proses editing yang dilakukan menggunakan adobe Premier Pro CC untuk memotong dan menggabungkan video serta software Adobe After Effect CC untuk animasi teks dan gambar.

Tahapan Ketiga yaitu Evaluasi, Pada model pengembangan ini di kenal 3 bentuk untuk menilai kualitas dari produk yang dikembangkan yaitu Expert Review, evaluasi 
One to one, dan evaluasi small group. Hasil uji coba media Video Knowledge Capture mata kuliah difusi inovasi ini, yang dilakukan oleh expert review didapatkan sebagai berikut :

Tabel 1 Rata-rata hasil Evaluasi Expert Review

\begin{tabular}{lc}
\hline \multicolumn{1}{c}{ Responden } & Rata-rata \\
\hline Retno Widyaningrum, & 3,81 \\
S.kom, M.M (Ahli Materi) & \\
Diana Ariani, M.Pd & $3,, 89$ \\
(Ahli Media) & \\
\hline \multicolumn{1}{c}{ Total Nilai Rata-rata } & 3,85 \\
\hline
\end{tabular}

Berdasarkan penilaian yang dilakukan oleh para ahli (Expert review) video yang dikembangkan ini mendapatkan nilai rata-rata 3,85. Angka tersebut didapatkan dengan menghitung rata-rata setiap ahli, ahli materi memberikan nilai rata-rata 3,81 sedangkan, ahli media memberikan nilai rata-rata 3,89. Nilai dari kedua ahli materi dijumlah dan dibagi dua, maka didapatkannya nilai rata-rata expert review pada pengembangan video knowledge capture yaitu 3,85. Video ini dapat dikatakan Sangat Baik.

Tabel 2 Rata-rata hasil Evaluasi One to One

\begin{tabular}{cc}
\hline Responden & Rata-rata \\
\hline Dimas Nur Pahlevy & 3,67 \\
Lucky Oktavianto & 3,67 \\
Annisa Aprilia & 2,50 \\
\hline Total Rata-rata & 3,28 \\
\hline
\end{tabular}

Berdasarkan penilaian secara One to One didapatkan nilai rata-rata akhir yaitu 3,28. Nilai tersebut dapat dikategorikan Sangat Baik.
Tabel 3 Rata-rata hasil Evaluasi Small Group

\begin{tabular}{cc}
\hline Responden & Rata-rata \\
\hline Shaffiya Rasidha A. & $\mathbf{3 , 6 7}$ \\
Anugrah Gita Putra & $\mathbf{3 , 6 7}$ \\
Karina Almira D. & $\mathbf{2 , 8 3}$ \\
Hakim Usmanto & $\mathbf{3 , 5 0}$ \\
Ragah Samudra & $\mathbf{3 , 4 2}$ \\
\hline Total Rata-rata & $\mathbf{3 , 4 2}$ \\
\hline Berdasarkan penilaian & secara Small \\
Group pada Mahasiswa Teknologi Pendidikan \\
angkatan 2017 didapatkan nilai rata-rata akhir \\
yaitu 3,42. Nilai tersebut dapat dikategorikan \\
Sangat Baik.
\end{tabular}

Berdasarkan nilai rata-rata yang diperoleh ketika melakukan review expert yaitu sebesar 3,85, pada One to One didapatkan nilai 3,28, dan Small Group sebesar 3,42. Dari kesimpulan ketiganya, dapat diambil kesimpulan bahwa pengembangan video knowledge capture pada Mata kuliah difusi inovasi Pendidikan ini Sangat Baik.

Produk Video Knowledge Capture ini dapat digunakan oleh setiap mahasiswa baik yang sudah pernah maupun yang ingin mengampuh mata kuliah Difusi Inovasi Pendidikan. Video ini dapat diakses melalui elearning Hylearn FIP pada courses yang ada. Selain itu, mahasiswa juga dapat mengakses video melalui channel youtube sehingga dapat dipelajari dimana saja. Untuk mengakses video di platform youtube bisa melakukan dengan scan QR Code berikut:

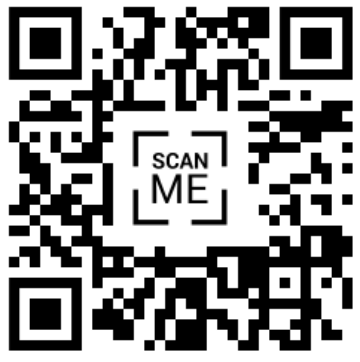




\section{Ardiansyah | JPI/Vol.o3/No.01/2020| H. 09 - 16}

\section{SIMPULAN}

Pengembangan

penelitian

menghasilkan sebuah video knowledge capture

pada Mata kuliah difusi inovasi Pendidikan di prodi teknologi Pendidikan. Pengembangan video ini guna memfasilitasi mahasiswa untuk belajar dan mendapatkan pengetahuan yang sudah dikemas dalam bentuk video. Video ini dikembangkan secara sistematis menggunakan Model Pengembangan Video Nonlinear oleh Pustekkom. Berdasarkan nilai rata-rata yang diperoleh ketika melakukan review expert yaitu sebesar 3,85, pada One to One didapatkan nilai 3,28, dan Small Group sebesar 3,42. Dari kesimpulan ketiganya, dapat diambil kesimpulan bahwa pengembangan video knowledge capture pada Mata kuliah difusi inovasi Pendidikan ini Sangat Baik.

\section{DAFTAR PUSTAKA}

Yusufhadi Miarso, "Menyemai benih teknologi pendidikan”, (Jakarta: Kencana , 2004). h. 458

Ade Hadiati Nuzuliana, Fauzi Bakri, Esmar Budaya. 2015. "Pengembangan video pembelajaran fisika pada materi fluida statis di SMA". Vol.IV

Chen, W. F. 2012. An Investigation of Varied Types Of Blended Learning Environments on Student Achievement: An Experimental Study. International Journal of Instructional Media., 39 (3): $211-218$

Situmorang, Robinson. Media Televisi, Pengetahuan Dasar Televisi dan Teknik Penulisan Naskah (Jakarta: Pustekkom,2006) h. 11H

Cecep Kustandi, Bambang Sujipto, Media Pembelajaran Manual dan Digital, (Bogor : Ghalia Indonesia, 2011), hal. 21

Rabab El-Sayed et al.2013. Video-based lectures: An emerging paradigm for teaching human anatomy and physiology to student nurses. p.216

Sharon E Smaldino, Deborah L Lowther, and James D Russel. Intructional teknology and Rawamangun, 2011) Hal. 405 